Article

\title{
Frustrating Beginnings: How Social Ties Compensate Housing Integration Barriers for Afghan Refugees in Vienna
}

\author{
Josef Kohlbacher \\ Institute for Urban and Regional Research, Austrian Academy of Sciences, 1030 Vienna, Austria; \\ E-Mail: josef.kohlbacher@oeaw.ac.at
}

Submitted: 4 February 2020 | Accepted: 12 May | Published: 28 July 2020

\begin{abstract}
In this article, we present findings from a recent (2017-2018) qualitative survey on the integration of Afghan refugees in Vienna. Vienna is by far the largest city in Austria with a diversified labour and housing market and a multi-faceted (migrant) economy. It doubtlessly is the most attractive 'arrival city' in Austria. Moreover, Vienna has received the bulk of refugees during the so-called 'refugee crisis' of 2015-2016 and before. The analysis will focus on Ager and Strang's (2008) argument, which characterizes housing as a core domain in integration. Housing constitutes a potential means of supporting integration into domains other than the labour market. In the process of housing integration, researchers (Aigner, 2018; Borevi \& Bengtsson, 2015) have emphasized the relevance of refugees' social ties with family and co-ethnic groups, whereas the importance of inter-ethnic networking with members of the receiving society remains insufficiently explored. The majority of the 65 interviewees had emphasized the importance of refugees' social ties for their efforts towards structural integration. This analysis therefore aims at describing Afghans' challenging access paths into the local housing market, and the outstanding compensatory relevance of social ties in this process. Thus, we can identify special constraints (e.g., 'Afghanophobia,' exploitative conditions) and coping strategies of this under-researched 'newcomer' group of refugees in Austria.
\end{abstract}

\section{Keywords}

Afghan refugees; housing market integration; integration challenges; social networks; social ties

\section{Issue}

This article is part of the issue "Urban Arrival Spaces: Social Co-Existence in Times of Changing Mobilities and Local Diversity" edited by Yvonne Franz (University of Vienna, Austria) and Heike Hanhörster (ILS-Research Institute for Regional and Urban Development, Germany).

(C) 2020 by the author; licensee Cogitatio (Lisbon, Portugal). This article is licensed under a Creative Commons Attribution 4.0 International License (CC BY).

\section{Introduction}

The starting point for this analysis was a self-financed pilot study ( $\mathrm{N}=19$ Afghan interviewees) during the winter 2015-2016, which provided an initial picture of integration paths of Afghan refugees in Vienna. Many respondents had emphasized the relevance of social ties established during the period in which the 'refugees welcome' culture had been dominant, which have had positive consequences for structural integration (Kohlbacher \& Schiocchet, 2017). These results led to a qualitative survey financed by the Federal Ministry for Europe, Integration and Foreign Affairs of the Republic of Austria, focusing on opportunities and constraints for the inte- gration of Afghans, who are still an overtly underresearched diaspora in Austria. This survey aimed at filling this empirical gap and providing insight into the integration challenges of this community. The research topics ranged from value orientations and educational, housing, and labour market integration to gender role models and religiosity.

The focus was the urban context of Vienna, which is characterized by a shortage of affordable housing. In this complex constellation, Afghans with their very limited market know-how and mostly lacking financial resources have to find accommodation within four months after receiving a positive asylum decision. Their struggle for obtaining housing results from a combination of individ- 
ual strategies and resources, complex local processes of housing production and consumption, housing policies, and residential norms.

Our explorative analysis will describe Afghan refugees' access paths into Vienna's housing market, outlining economic, systemic, and xenophobic constraints for the housing integration of this 'new group' of refugees in Austria. The theoretical approach emphasizes the importance of housing for structural integration. This article will address the following questions: (1) How do refugees manage the transition into the regular rental market, and what are their main challenges? (2) Which compensatory role do social networks play in this complex process?

Housing and labour market integration of the many asylum seekers entering during 2015-2016 still represent the biggest challenges for municipal policies in Vienna, which, despite an increased construction rate, are not able to rapidly compensate the housing shortage.

\section{Setting the Local Scene of Access to Housing: Political and Housing Conditions}

\subsection{Vienna: Austria's Immigration Focus}

Vienna is by far the largest city in Austria with $1,897,491$ inhabitants in 2019, of whom 688,884 are foreign-born. Between 2004 (when the total number of inhabitants was $1,619,410$ ) and 2019 , the total population grew by $17.8 \%$, peaking through the influx of refugees in 2015 (Stadt Wien, 2019). Though Vienna has a long tradition of being the immigration magnet of Austria, large-scale immigration from Afghanistan is a recent phenomenon. About $40 \%$ of the annual migration influx to Austria is concentrated in Vienna, characterizing it as the most attractive 'arrival city' in Austria and making it well-suited for research in housing integration, which is a particular Viennese challenge.

During the so-called 'refugee crisis' of 2015-2016, the influx from the Middle East and Afghanistan has increased (Statistics Austria \& KMI, 2017). In the peak year of 2015, 88,340 persons (25,563 Afghan) applied for international protection. In the same year, 1,263 gained subsidiary protection (Bundesministerium für Inneres, 2018 , p. 4). Afterwards, this decreased to $42,285(11,794$ Afghan) applications in 2016, 24,735 in 2017 (3,781 Afghan), 13,746 (2,120 Afghan) in 2018, and 12,886 (2,979 Afghan) in 2019 (Bundesministerium für Inneres, 2015, 2016, 2017, 2018, 2019). In 2019, Afghans constituted the biggest proportion (23\%) of asylum seekers, followed by Syrians (21\%), Iraqis, Iranians, Somali and Russians, mainly Chechens (each about 6\%).

Outside Vienna, asylum seekers live in (sometimes overcrowded) federal group accommodations, often in remote areas. This has proved to foster stigmatization. Vienna follows a strategy of distributing asylum seekers into small-scale asylum centres and private accommodation units. Thus, in September 2019 only $29 \%$ of the asylum seekers receiving basic provision lived in 57 larger asylum homes, while $71 \%$ lived in small private accommodations distributed across the urban area (Fonds Soziales Wien, 2019, p. 2). Although we have no official statistics on the internal migration of Afghans who have received asylum, it can be assumed that after gaining asylum or subsidiary protection (according to Directive 2011/95/EU, given to a third country national who would face a real risk of suffering serious harm if the person returned to the country of origin), the majority has been moving to Vienna. This is supported by own qualitative data and by estimates referring to refugees of different origins, of whom $60 \%$ to $80 \%$ intend to move to the capital (Addendum, 2018, p. 4). Levels of needs-oriented minimum basic income, varying according to province, also play a relevant role in this regard (Müller, 2016). The spatial distribution of the Afghan-born population in Austrian political districts is uneven. Although the proportions are very low throughout, according to official statistics $(0.05 \%$ to $0.35 \%$ of the residential population per district), the highest rates occur in Vienna and the provincial capitals Linz and Graz (each between $0.53 \%$ and $0.85 \%)$.

\subsection{Housing Shortages and Blatant Rental Increases: Europe's Unique Metropolis of Social Housing}

As is the case in other European metropolises, Vienna's transition from an industrial city to one with a dominant service sector leads to increased socio-spatial polarization. On the labour market, neoliberal trends such as restrictive wage policies and rising unemployment have led to an increase of socio-economically marginalized groups within the population, particularly in the immigrant segment.

Government involvement in housing production and consumption has a strong tradition not only in Vienna, but in Austria as a whole. Inequality is combatted by a policy of social equality, with the city developing measures aimed at reducing social disparities through a network of social welfare institutions and subsidies. Welfare policy includes interventions in the domains of housing, such as subsidised loans, subsidies for non-profit housing companies, housing benefits, support for single mothers and families, etc. The municipal "integration-oriented diversity policy" (Stadt Wien Magistratsabteilung 17, n.d.) combines the historical heritage of the city, being Austria's (last) socio-democratic stronghold and being the capital with the largest stock of municipal housing in Europe. The housing sector is quite different from that in a purely free-market society. It is outstanding in Europe because of its high share of subsidized housing (about 450,000 apartments), of which 220,000 units in about 1,800 residential complexes are municipalityowned (Wiener Wohnen, 2019). Thanks to political emphasis on affordable housing, Vienna is still in a better position than other metropolitan cities where social housing has been neglected (Musterd, 2020). However, 
increased polarization in spatial dimensions could not be prevented, and housing shortages and rent levels have risen rapidly during the last decade (Pechtl, 2019). According to microcensus data, the gross rent level rose by $30.1 \%$ between 2008 and 2016 (Arbeiterkammer Wien, 2017, p. 15).

The housing market is segmented. According to microcensus data, $24.4 \%$ of the stock was municipal housing, $19.9 \%$ cooperative housing, $30.2 \%$ belonged to the rental segment, and $21 \%$ was owner occupied. $4.5 \%$ belonged to other types. In 2013 about $43 \%$ of third-country nationals, a category to which Afghans also belong, were living in the private rental segment (Kohlbacher \& Reeger, 2020, p. 106). There is a gap between the political claims concerning the relevance of social housing for refugees and the reality of accessibility (Franz \& Gruber, 2018, pp. 98-100). Municipal housing provides an alternative for foreign citizens with a longer duration of stay but because of legal restrictions (a minimum of 2 years' legal residence in Austria's capital at the same address), this segment is not accessible to persons who have recently been granted asylum and who have just left their asylum shelters. Refugees are excluded from co-operative apartments because they lack the necessary capital. Compared with other EU metropolises, Vienna's position in terms of the supply of social housing is positive, but it is now under pressure through real estate speculation and immigration. The imbalance between immigration to Vienna and new residential construction is mirrored in the fact that, for each newly constructed apartment, 4.8 'new' immigrants (including labour migrants and persons granted asylum), arrived in 2016 (Addendum, 2018, p. 5). Thus, the population with a background of flight is unequally distributed across the housing market segments (Aigner, 2016).

Considering the majority of asylum seekers entering around 2015, Afghans belonged to the socioeconomically marginalized. Their educational and professional qualifications were lower than that of Syrians and Iraqis. The 'competence check' of the Austrian Labour Market Service showed that only $7 \%$ of incoming Afghans were university graduates (Arbeitsmarktservice, 2016). This limits their financial scope for rental payments and directs their housing demand to working-class neighbourhoods. Socio-economic status is the determining parameter for living in certain neighbourhoods. Within the city, the less attractive areas with a high percentage of rental housing units from the Founders' Period (old stock built from 1860 to 1914) are the favoured living areas for financially disadvantaged immigrants. According to the last official census in 2011 , about $50 \%$ of all immigrants lived in six of the 23 Viennese districts, Leopoldstadt, Favoriten, Ottakring, RudolfsheimFünfhaus, Brigittenau, and Landstraße (Hatz, Kohlbacher, \& Reeger, 2015, pp. 80-82). Although official data is yet unavailable, one can assume from qualitative interviews that most Afghans find accommodation in the older housing stock of the above-mentioned districts. Whether this should be assessed positively or negatively (Peach, 1996, p. 137) cannot be decided in the Afghan case. Since immigration from Afghanistan is a recent phenomenon, there are no existing residential areas with high concentrations ('ghettos') of Afghans. All respondents live in ethnically mixed neighbourhoods. Based on the analyses of Massey (1990) and Massey and Denton (1993), it could of course be argued that by concentrating poverty, segregation creates an unfavourable social environment for financially disadvantaged immigrants. Residential areas of low-status African Americans, however, differ completely from Austrian working-class districts. Since 1974, the 'soft' urban renewal programme of the Vienna municipality has subsidised the renovation of about 340,000 apartments in these districts, which were inhabited in 2011 by approximately 800,000 persons (Ebner, 2013).

Furthermore, public authorities are largely delegating responsibilites for housing access of refugees who were granted asylum to NGOs. Usually, the impact of the municipality and of NGOs is rather limited and capitalistshaped housing market mechanisms determine how Afghans obtain access to housing and in which market segments, districts, and neighbourhoods they can live. Welfare organisations (e.g., Diakonie, Caritas) offer advice and support but have a very limited stock of emergency housing at their disposal. This is mostly reserved for persons in extremely precarious situations, such as single parent families, traumatized, and chronically ill persons.

\section{Afghans' Confrontation with Housing Market Realities}

Although consultation services are available, the solution of the accommodation problem remains a challenge. Private market rents have significantly risen in the urban agglomeration. Persons granted asylum are not restricted in their choice of place of residence, but the majority moves to Vienna. Concerning the distribution into housing market segments, reliable data for Austria is still unavailable. More is known about local housing integration of persons granted asylum in Germany (see Bundesinstitut für Bau-, Stadt- und Raumforschung, 2017), and parallels to Austria are probable.

The relevance of municipal housing varies in different countries and municipalities (Francis \& Hiebert, 2014). In Austria it varies due to changes in the entry requirements (e.g., a minimum duration of stay in a city) and in the size of stock. Usually, entering the private rental market is the only realistic option, although it is not easy for Afghans, due to several challenges. One major problem is that many Afghan households only receive the needsoriented minimum basic income (in Vienna a monthly EUR 688.01 towards living costs, EUR 229.34 housing assistance plus EUR 247.68 per child; see Arbeiterkammer Wien, 2020) while affordable housing is extremely limited in metropolitan areas. The average net rent, excluding heating costs, for a 60 square meter flat equals 
12.47 EUR/sqm (in 2016 this value was $12.10 \mathrm{EUR} / \mathrm{sqm}$ ) and 14.97 EUR/sqm for a 30 square meter unit (or 14.23 in 2016; see Wohnungsboerse, 2020). This is aggravated by the fact that, according to an expert from the municipality, "there is a shortage of private flats in general and in particular of private rental flats." At the counselling centre another expert said:

The apartments on the private rental market in which the refugees have to live are of an extremely bad quality and are completely overpriced. They also have limited and very short contracts. The housing situation of many, many refugees who are contacting us is so bad that one can hardly imagine it.

The availability of suitable housing is just one problem. Afghans encounter additional obstacles. First, there is little knowledge of the local rental market (Flatau et al., 2015). Apartment seekers often do not meet the rental market requirements since they cannot provide occupation references and prove creditworthiness. They are discriminated against by lessors and real estate agents due to their visibly belonging to an ethno-religious minority, their asylum status, and their source of income (often welfare; see Murdie, 2008). Xenophobic dicrimination also plays a role, as pointed out by an expert at the University of Vienna: "Apartment seekers with a 'foreign' name have great difficulties and will often not even get a viewing appointment." Furthermore, said an expert at the municipality: "People rarely want to rent their flat to an unknown culture, unknown persons who are granted asylum, without a job, entitled to needs-oriented minimum basic income." Living spaces often do not suit Afghans' household structures, which consist predominantly of single males or larger families (Aigner, 2018).

The search process is further burdened by the uncertainty regarding their legal status. A considerable share of Afghans is not granted asylum but subsidiary protection, which depends on the changing security situation in the regions of origin. An Afghan woman, aged 46, living in Austria since 2011, reported: "I had to wait three years until I could join my husband already living here." Muslims and 'visible' groups (Afghans should be included as well as Chechens and Africans) experience the most precarious starting conditions (see Murdie, 2010). With a longer duration of stay, many refugees improve their financial leeway and their housing market position. The improvement depends on their level of education and on their ability to achieve better paying labour market positions.

The "most common solution" (Francis \& Hiebert, 2014, p. 76) to these challenges is to pay excessive rents for inadequate and overcrowded housing, which often constitutes transitory accommodation. According to an expert from the municipality:

Flats are rented to groups, though the person is not the real owner. The person himself has rented the flat and has sub-rented it to five persons. A small apartment, only one-room apartment in which five persons have to live and the tenant collects the money. If the owner realizes the situation he says: 'Move out immediately!' Then they stand on the street with nothing, without rights.

In search of adequate housing, many refugee households move several times before they find appropriate housing (compare also Ager \& Strang, 2008).

To compensate for the deficits mentioned, refugees urgently need information and the active support of persons familiar with the local housing market. Thus, for the majority, social networks are the most relevant 'key' towards accessing the housing market and reducing the risk of exploitation.

\section{Relevance of Social Networks in Housing Integration}

\subsection{State of Research}

A plethora of empirical studies documents the relevance of social networks for providing information about labour market opportunities. Less is known about the housing market. This analysis focuses on Ager and Strang's (2008) argument, in which they stress housing as an important domain of integration, although the interconnections between the dimensions of integration are interpreted differently (Adam et al., 2019; Penninx \& Garcés-Mascareñas, 2016). In Esser's (2001) integration concept, the reference areas in the micro level (social integration) and the macro level (system integration) are complexly interwoven. Heckmann's (2015) concept distinguishes the four dimensions of structural, cultural, social, and identificational integration, emphasizing manifold interconnections. There is no doubt that the housing situation has impacts on other domains of structural integration, such as education and labour (Bosswick, Heckmann, \& Lüken-Klaßen, 2007; Danzer \& Ulku, 2011).

Social interactions 'produce' weak and strong ties. Granovetter (1973) refers to strong ties as close relationships (e.g., friends) and weak ties as more tenuous relationships. All of these ties increase the availability of resources (Granovetter, 1995; Gurak \& Caces, 1992). Research has mainly focused on the effect of strong ties for social support in challenging situations. Closer ties are often a 'vehicle' for integration into the labour and housing market (Hurlbert, Haines, \& Beggs, 2000), but Granovetter (1973, p. 1360) emphasized "the strength of weak ties." This relation we intended to verify by our qualitative data in general and for a selected national group in particular, as there is a research gap concerning the relevance of weak ties for housing access (Aigner, 2016). Fararo and Skvoretz (1987) pointed out that weak ties require a lesser time investment and therefore allow a greater number of ties to evolve, resulting in an overall network with greater connectivity. Smith (2012) 
investigated the manifold possibilities and benefits of weak ties. The evidence suggests that the use of informal contacts varies according to age, ethnicity, and location. Immigrants in poor neighbourhoods and in large cities are more likely to use informal networks. Weak interethnic ties are relevant in the field of social integration, which is a process of exchange, and which starts with the establishment of first contacts (Wren, 2007). Networks based on personal ties, as well as organizational relations (e.g., schools, professional associations, agencies, recruiters, and other intermediaries), are relevant (see Arango, 2004, p. 28; Fawcett, 1989).

Social networks are the core of social capital. Individual characteristics of persons concerning their capacity to establish social ties (and to mobilise resources), such as extroversion, gender, or social class are obviously relevant (Murdie, 2008). Social capital theory contends that social relationships are resources that can lead to the development and accumulation of human capital (Häuberer, 2019, p. 36). For Coleman (1988, 1990), social capital exists between actors. It is not attributable to a single actor as is economic capital. Putnam (2000, p. 167) has added trust and norms to the social network core. Bourdieu (1986) defined social capital at the individual level. Lin (2001) adopted an individualistic and actionistic view of social capital, adding resources to the social network. For him social capital is "resources embedded in a social structure that are accessed and/or mobilized in purposive actions" (Lin, 2001, p. 29). Social capital may also be interpreted as "any feature of a social relationship that yields benefits" (Lin, 2001, p. 29), which seems to be a suitable basis to understand many Afghans' interpretations of 'useful' networks. These include extended family members, friends and acquaintances, German language teachers, volunteers, and NGO staff in transitional housing and counselling centres (see Francis \& Hiebert, 2014).

Concerning refugee integration, the mechanisms of social networking have been investigated, e.g., by Atfield, O'Toole, and Brahmbhatt (2007), Brücker et al. (2016, pp. 121-128), as well as McMichael and Manderson (2004). Compared to labour migrants, asylum seekers and persons entitled to asylum are disadvantaged in their networking abilities. Due to the special conditions of asylum (e.g., living in asylum homes), they often lack extensive social networks in the receiving context (Bergeron \& Potter, 2006). Cheung and Phillimore (2013, p. 536) discovered that the mere access to social networks is not enough to enhance access to employment. Rather, language competence, pre-migration qualifications and occupations, and time spent in the receiving country are most important in accessing work opportunities. However, the absence of social networks does appear to have a detrimental effect on access to the labour market.

Research in housing integration (e.g., Borevi \& Bengtsson, 2015; Lauer \& Yan, 2007) emphasizes the relevance of social ties with co-ethnics, but the importance of ties with members of the receiving society is still under-researched. Ryan (2011) identified a research gap, as more attention should be given to the ways in which immigrants access and maintain different types of networks in varied social locations and with diverse people. In the case of Vienna, only very little is known about the housing paths of third-country nationals. One has to mention the analyses of Giffinger and Reeger (1997) for Turkish migrants and of Lichtenberger (1984) and Kohlbacher and Reeger (2007) for migrants from former Yugoslavia. The first study about housing integration of refugees in Vienna was done in 2015-2016 by Aigner (2018), based on a sample of 25 respondents of various origins (6 from Afghanistan).

\subsection{Methods}

\subsubsection{Qualitative Ethnographic Approach}

According to Franklin (2008), the qualitative investigation of housing paths has the capacity to integrate structural and subjective dimensions. The value of ethnographic methods for the interpretation of housing access processes lies in the embedded nature of these processes in complex structures of integration processes, market conditions, everyday life, and social relations (Ronald, 2001, pp. 416-419). Using a qualitative approach allowed us to include the perspectives both of refugees and of experts.

Concerning Vienna as an arrival space, we know that the refugees who were interviewed were living in many different parts of Vienna, but because of many refusals to reply, we could collect little data about their integration in these neighbourhoods of residence. This study does not aim to make representative claims about refugees' general degree of success on the housing market. Instead, it seeks to contribute to a better understanding of Afghans' complex problem constellations and paths of access into the housing market. The limitations of the sample in terms of country of origin influence the results because this influences the likelihood of being accepted as a tenant.

\subsubsection{Sampling}

One goal of the sampling process was to interview a group that was as diverse as possible in order to include the effects of different socio-economic and demographic variables that usually have an impact on the integration process. A total of 65 persons (27 female, 38 male) with varying lengths of stay in Austria were interviewed in 2017-2018. Respondents were recruited with the support of organizations of the Afghan diaspora through snowball sampling. Whereas 13 Afghans had already fled before 2000, 23 moved between 2000 and 2010, 11 during 2013-2014 and 18 came in 2015 or later. 52 interviews ( 33 with men and 19 with women) could be conducted in Vienna. Mirroring the flight movements of Afghans to Europe in general, there was a 
dominance of younger respondents. 50.1\% were born between 1990 and 1999, only 5 were born between 1950 and 1959, and only one person was older than seventy years. Single young males predominate among the recently-fled respondents, mirroring the high proportion of this group among refugees that have been coming to Austria since 2010 . Of the interviewees, $8 \%$ did not even have a basic education, $21 \%$ had finished compulsory education, whilst $25 \%$ held university degrees. All interviews (duration between one and two and a half hours) with Afghans were conducted in Farsi-Dari and then translated into German. The data set was augmented by 13 expert interviews with representatives of the Ministry for Europe, Integration and Foreign Affairs, the Austrian Integration Fund (ÖIF), the Vienna Municipal Department for Integration and Diversity, NGOs, Afghan associations, etc. There also was a focus group discussion of four hours with four experts, two volunteers, four researchers, and four Afghan refugees, which took place at the Institute for Social and Cultural Anthropology of the University of Vienna. The quotes used in this article are extracts from the interviews translated into English.

The material was coded with atlas.ti (using substantial and theoretical codes) and analyzed by qualitative content analysis using the inductive and recursive approach of Grounded Theory (Glaser, 1978). Through the method of permanent comparison, data collection as well as coding and analysis of the data took place simultaneously. The supplementary fieldwork consisted of participation in formal as well as informal activities and participant observations (e.g., at football matches and musical or private events).

\subsection{Perspectives and Experiences of Afghans}

We knew from the pilot study that social ties are often quickly established during the initial phase of stay. Extroverted persons readily accomplish this. Thus, various individual networks exist within one community: young male or female refugees, families with children, or persons belonging to certain ethno-religious groups (e.g., Hazara) for example each form their own types of networks. Single persons are usually more eager to establish strong and weak social ties with Austrians than Afghan families since the former have left behind their whole social system.

\subsubsection{Financial and Housing Market Challenges}

Social ties with diverse people in varied social locations influence the segment-specific and spatial location of Afghans. We know from our data that networks are both a motivation and a means for the selection of accommodation and its location within the city. This, however, differs in accordance with socio-economic status and financial capacities. All Afghan respondents had lived in transitional housing before they entered the private rental market. A complex of closely interrelated factors charac- terises the difficult transition paths into Vienna's private rental market. In these aspects, the situation of Afghan interviewees clearly differs from that of labour migrants and from the overall situation in the city. Because the demand for affordable housing in Vienna significantly exceeds the supply, almost all interviewees had serious trouble finding accommodation: "To find a flat is really a big calamity," said an expert from the municipal department. Considerable competition in the housing market is a challenge faced by everybody searching for apartments, because labour immigrants, students, and other low-income households are also trying to find affordable housing in the same 'working-class' districts. The respondents characterized the situation as extremely harsh, expecting these conditions to continue. A quote from an expert interview illustrates this:

The biggest challenge is at the beginning....Maybe they have found an apartment which is completely problematic, and they know that after two years they will have to leave it. The flat is totally destroyed. They have paid an extremly high rent for it, a commission and maybe a deposit to a company that has lent them the money. Thus, they are fully in a market situation...they don't know the language, they have health problems,...there are so many barriers at the beginning that it is not possible to manage all these problems parallelly....For two or three years they have to fight that basic needs be met until they will get the needs-based minimum income....There may also be some kind of financial 'backlog' of rental payments which they were unable to pay.

\subsubsection{The Role of Support by Social Ties}

Almost all interviewees reported that gathering information about vacant apartments or rooms communicated through social networks is the most successful routes towards obtaining lodgings (see Adam et al., 2019). Networks rather than internet real estate search platforms were the greatest help. An expert from an NGO counselling centre explained: "Thus, the community plays the leading role for surviving and for finding accommodation." Not only the sharing of relevant information, but also the rendering of financial support, which may constitute one-time payments or long-term financial assistance, is frequently reported:

When we arrived, the Afghans helped us a lot with 100 or 150 euros. My husband could rent a flat with his own savings and the additional money which we could get this way. (Woman, aged 33, in Austria since 2016)

A female interviewee, aged 46, living in Austria since 2011, said: "I have a flat in the 10th district and my colleagues, my acquaintances, and friends support me with money." 
Refugees can benefit greatly from social contacts with locals, compensating their lack of knowledge of the local rental market, sharing experiences during the search process, and dealing with lessors or institutional providers of housing (Anthias, 2007). Through networking, the Afghans obtained relevant information and assistance during viewing appointments and gained language support when negotiating with lessors and finalizing the rental contract:

After the positive asylum decision, we had to leave the asylum shelter within four months. A female teacher from the nearby school supported us. She had a flat where a hospital nurse was living temporarily. After two months, this person left, and we arranged a viewing appointment. It is a very beautiful apartment with a garden plot. Austrian people are really very helpful. (Male, aged 45, in Austria since 2013)

From the interviews it is evident that negotiations with lessors often need the support of an Austrian or another person of trust speaking fluent German who can intervene on their behalf, help with translation problems, and reduce doubts concerning (financial) reliability:

For finding a flat I contacted all my Afghan and Austrian friends and I posted on Facebook. My actual flat I have found with the help of an Austrian friend. She informed me that she would arrange a viewing appointment. After viewing the flat together with this friend, I could sign the rental contract immediately. (Male, aged 36, in Austria since 2010)

An Afghan woman, aged 21, living in Austria since 2016, narrated: "A female volunteer from the Red Cross...helped us to find this apartment owned by an acquaintance of hers."

Social ties with other Muslim groups also may help obtaining housing (see Cheung \& Phillimore, 2013), but there are pronounced ethnic dividing lines between the Muslim organizations in Vienna. Some interviewees mentioned professional intermediaries from the Afghan or other Muslim communities who are paid to place apartment seekers in apartments. These services are usually connected with considerable financial profit resulting from the tight market situation and excessive fees are thus often charged. Fearing homelessness, the Afghans were unwilling to provide detailed information about this problem. An Afghan expert from the municipal department reported:

We have some persons in the Afghan community who take advantage of this situation. They send apartment seekers to a certain flat. Then the refugees stay there for three months. Then the property management throws them out because they don't have a rental contract. They even don't know what a rental contract is. They are exploited.... In a kind of corruption they also issue pay slips for other people so that these Afghans can get a flat. For this activity, they claim provision. The legal provision is two monthly rents, but these persons want three monthly rents. These pay slips are absolutely required by the Afghans. To find a flat is really a big calamity....Unfortunately, we hear that certain persons profit from this situation as real estate agents. They convey apartments on the basis of a 'small' commission of 500 euros, which is in fact extremely much money for these persons. And you must know that the rent for these apartments also is $\mathbf{5 0 0}$ euros. $\mathbf{5 0 0}$ for $\mathbf{2 5}$ square metres, which is extremely much for a refugee granted asylum and having no job at the beginning.

The transition to the private rental market is often linked to precarious rental arrangements with short-term, insecure, or even illegal rental contracts. Often there is a lack of basic information about tenants' rights (e.g., eviction protection, allowable rent, ancillary costs, and deposits). Afghans living in insecure housing situations (mostly young single men) are constantly at risk of becoming homeless, as an interviewee reported:

When I was 18 , I had to leave the youth centre in the 12th district and got a place in a Caritas shelter near the Western Railway Station in the 15th district. There I lived for two months. Then I was homeless for two weeks. I had neither shelter nor money. Some days I slept outdoors near the River Danube....After my brother had found a job, I could join him and moved into his apartment. (Male, aged 21, in Austria since 2015).

Shared flats prove to be a frequent strategy, using existing and extending social ties after leaving refugee accommodations. Single rooms are easier to finance than whole apartments. Renting a room in a shared flat is usually bound to a temporary contract but this does not differ substantially from temporary rental contracts for whole apartments:

Young Afghan men have the opportunity to find shelter anywhere, possibly protracting this condition of semi-homelessness. They often solve this problem in renting middle-sized apartments in larger groups. There they frequently become victims of exploitative relationships. (Expert, NGO)

Temporary contracts are also a frequent model for students who sub-let their rooms while studying in other EU countries. Thus, some refugees share a flat with Austrian students who become helpful friends in everyday life. These contracts are less attractive for many other tenants, and thus the competition in this legal segment is less harsh. A considerable advantage of flat sharing is the possibility of expanding supportive social ties. Living with friends and gaining new social ties can become an impor- 
tant practical support for single refugees whose families were left behind. It is no option for families searching for accommodation.

The Afghans' scope for action and decision-making is extremely limited. Most interviewees did not have any alternative to the flats or rooms they were living in at the time of being interviewed. Refugees from Afghanistan are also confronted with an additional challenge. As the result of a negative media presence in the wake of criminal offenses, a certain xenophobic mood against the Afghan community evolved simultaneously with an increase in generalized Islamophobia (Hajek, 2019, pp. 9-19). The outcome for housing integration was as follows, according to an expert from the University of Vienna: "Afghans actually have no good standing searching for an apartment or a job. This is because of certain criminal offenses and media reports. People don't have a good opinion about Afghans." Furthermore: "Apartments are available, but they don't get them because there is their negative image" (expert, Afghan organisation). Afghans are among the most stigmatized groups:

It is because of all the negative things that have been in the newspapers, so Afghans and Chechens have very bad cards in this thing....You take someone else, if two people come, one is an Afghan and the other is from somewhere else, then you take that one and leave the Afghan, because they say he is fighting and things like that. (representative, Afghan mosque)

\section{Conclusion}

This article presents results about the housing access paths of Afghans who have been granted asylum in Vienna. As among other immigrant groups, the characteristics of dwellings as market goods, the particular resources, and the dynamics of supply and demand affect housing access paths and housing conditions. Afghans could be identified as a particularly vulnerable group because of economic disadvantage and discriminatory practices. Afghans experience a highly competitive situation with manifold difficulties when moving from refugee accommodations into the rental segment. Limited affordable housing in Vienna constitutes a major general constraint. This is more pronounced in the central districts and with certain types of housing, namely larger apartments for families, with two or more rooms. This especially holds true for Vienna's rental market segments with unregulated pricing (mainly in the older stock of working-class districts), where chances are largely determined by the liquidity of the refugee household and by efficient networking.

It could be demonstrated that dimensions of housing quality and types of contract are determined by household-specific financial abilities and nationality. Many lessors reject applicants because of their foreign origin, legal status, poor language proficiency, and/or socio-economic characteristics, such as being a welfare recipient. In the case of the Afghans, who fall under generalized suspicion, a discriminatory mood can be detected.

Afghans rarely manage to find access to the housing market along 'native' pathways such as internet real estate platforms. Social networking is identified as the most frequent coping strategy towards overcoming challenges in the search for housing and counteracting discriminatory practices. Thus, their individual and groupspecific chances and their competitive position for accessing the market and for addressing particular dimensions of housing conditions are improved by intra- or inter-ethnic social ties, which provides additional financial resources and information, and mediates between demanders and suppliers. Networks include strong ties to friends and relatives in the Afghan community who provide information on vacant apartments or who pass their own apartments on to fellow Afghans. Moreover, weak ties between refugees and locals play an important role. These ties with volunteers, counsellors in NGOs, and German language teachers offer information and language support. The same persons may both be persons of trust and non-profit-oriented lessors. Thus, both kinds of social ties play a role in Afghans' access to dwellings in a segmented housing market. Weak ties often are very effective, supporting Granovetter's (1973) argument about the "strength of weak ties." Social ties are both a motivation and a facilitator for the selection of accomodation and of the spatial location of housing. Our findings further demonstrate that respondents do not have much choice regarding their housing decisions and are therefore often dissatisfied with the size of their dwellings, but only rarely with their location.

The findings of this study are subject to some limitations. One was the broad range of research topics covered by the survey, which made it impossible to gain deeper insights into refugees' modes of access and maintainance of different types of networks in varied social contexts and with diverse people. A more systematic investigation of the formation mechanisms, structures, and duration of the social ties would provide valuable insights. Another limitation is its 'snapshot' character. A further survey in 3 to 5 years would reveal whether the respondents had progressed on their housing paths. Thus, we plan further research to answer these questions.

There is a clear lack of institutional assistance for newly recognised refugees (particularly for young, single men) towards finding accommodation in the private housing market. Thus, the municipality should soon take measures to facilitate access to social housing and to shorten the waiting time. Finally, I want to stress the importance of involving all members of the urban society in the battle against discrimination in the private housing market.

\section{Acknowledgments}

The author of this study gratefully acknowledges all the input received by members of the Afghan community in 
Vienna and given by Gabriele Rasuly-Paleczek, PhD, from the Department of Social and Cultural Anthropology at the University of Vienna. This study was made possible with funding from the Federal Ministry for Europe, Integration and Foreign Affairs of the Republic of Austria. The author would also like to thank the four reviewers for their valuable feedback, which has greatly improved the original manuscript.

\section{Conflict of Interests}

The author declares no conflict of interests.

\section{References}

Adam, F., Föbker, S., Imani, D., Pfaffenbach, C., Weiss, G., \& Wiegandt, C. C. (2019). "Lost in transition"? Integration of refugees into the local housing market in Germany. Journal of Urban Affairs. Retrieved from https://doi.org/10.1080/07352166.2018.1562302

Addendum. (2018, April 28). Der Flüchtling als Mieter [The refugee as tenant]. Retrieved from https:// www.addendum.org/wohnen/der-fluechtling-alsmieter

Ager, A., \& Strang, A. (2008). Understanding integration: A conceptual framework. Journal of Refugee Studies, 21(2), 166-191.

Aigner, A. (2016). Über (Un-)Zugänglichkeiten, gute und böse Subwohnungsmärkte [About (in)accessibilities, good and bad subsegments of the housing market]. Asyl Aktuell, 3, 9-18.

Aigner, A. (2018). Housing entry pathways of refugees in Vienna, a city of social housing. Housing Studies, 34(5), 779-803.

Anthias, F. (2007). Ethnic ties: Social capital and the question of mobilisability. The Sociological Review, 55(4), 788-805.

Arango, J. (2004). Theories of international migration. In D. Joly (Ed.), International migration in the new millennium (pp. 15-35). Farnham: Ashgate.

Arbeiterkammer Wien. (2017). Mieten in Österreich und Wien [Rents in Austria and Vienna]. Vienna: Arbeiterkammer. Retrieved from https://www. arbeiterkammer.at/infopool/wien/Mieten_in Oesterreich_und_Wien_2008_bis_2016.pdf

Arbeiterkammer Wien. (2020). Mindestsicherung [Needs-based minimum income]. Arbeiterkammer. Retrieved from https://wien.arbeiterkammer.at/ beratung/arbeitundrecht/arbeitslosigkeit/ Mindestsicherung.html

Arbeitsmarktservice. (2016, January 12). Asylberechtigte auf Jobsuche [Persons granted asylum in search of jobs; Press release]. Arbeitsmarktservice. Retrieved from http://www.ams.at/ueber-ams/medien/amsoesterreich-news/asylberechtigte-auf-jobsuche

Atfield, G., O'Toole, T., \& Brahmbhatt, K. (2007). Refugees' experiences of integration. Birmingham: University of Birmingham and the Refugee Council.
Bergeron, J., \& Potter, S. (2006). Family members and relatives: An important resource for newcomers' settlement? Canadian Issues, 2006(Spring), 76-80.

Borevi, K., \& Bengtsson, B. (2015). The tension between choice and need in the housing of newcomers: A theoretical framework and an application on Scandinavian settlement policies. Urban Studies, 52(14), 2599-2615.

Bosswick, W., Heckmann, F., \& Lüken-Klaßen, D. (2007). Housing and integration of migrants in Europe. Strasbourg: The Congress and EuroFound Dublin.

Bourdieu, P. (1986). The forms of capital. In J. E. Richardson (Ed.), Handbook of theory of research for the sociology of education (pp. 241-258). New York, NY: Greenwood Press.

Brücker, H., Kunert, A., Mangold, U., Kalusche, B., Siegert, M., \& Schupp, J. (2016). Geflüchtete Menschen in Deutschland: Eine qualitative Befragung [Refugees in Germany: A qualitative survey] (IAB Report No. 9). Nuremberg: IAB.

Bundesinstitut für Bau-, Stadt- und Raumforschung. (2017). Integration von Flüchtlingen in den regulären Wohnungsmarkt [Integration of refugees into the regular housing market]. Bonn: BBSR. Retrieved from http://www.bbsr.bund.de/BBSR/DE/ Veroeffentlichungen/BBSROnline/2017/bbsr-online21-2017-dl.pdf

Bundesministerium für Inneres. (2015). Asylstatistik 2015 [Asylum statistics 2015]. Vienna: Bundesministerium für Inneres. Retrieved from https://www. bmi.gv.at/301/Statistiken/files/Jahresstatistiken/ Asyl_Jahresstatistik 2015.pdf

Bundesministerium für Inneres. (2016). Asylstatistik 2016 [Asylum statistics 2016]. Vienna: Bundesministerium für Inneres. Retrieved from https://www. bmi.gv.at/301/Statistiken/files/Jahresstatistiken/ Asyl_Jahresstatistik_2016.pdf

Bundesministerium für Inneres. (2017). Asylstatistik 2017 [Asylum statistics 2017]. Vienna: Bundesministerium für Inneres. Retrieved from https://www. bmi.gv.at/301/Statistiken/files/Jahresstatistiken/ Asyl-Jahresstatistik_2017.pdf

Bundesministerium für Inneres. (2018). Asylstatistik 2018 [Asylum statistics 2018]. Vienna: Bundesministerium für Inneres. Retrieved from https://www. bmi.gv.at/301/Statistiken/files/Jahresstatistiken/ Asyl-Jahresstatistik_2018.pdf

Bundesministerium für Inneres. (2019). Asylstatistik 2019 [Asylum statistics 2019]. Vienna: Bundesministerium für Inneres. Retrieved from https://www. bmi.gv.at/301/Statistiken/files/Jahresstatistiken/ Asyl-Jahresstatistik_2019.pdf

Cheung, S. Y., \& Phillimore, J. (2013). Social networks, social capital and refugee integration. Sociology, 48(3), 518-536.

Coleman, J. S. (1988). Social capital in the creation of human capital. American Journal of Sociology, 94(Suppl.), 95-120. 
Coleman, J. S. (1990). Foundations of social theory. Cambridge, MA: Harvard University Press.

Danzer, A. M., \& Ulku, H. (2011). Integration, social networks and economic success of immigrants: A case study of the Turkish community in Berlin. Kyklos, 64(3), 342-365.

Ebner, H. (2013). Wiener Stadterneuerung: Der Weg zur lebenswertesten Stadt [Urban renewal in Vienna: The path to the most liveable city]. Vienna: Carl Gerold's Sohn Verlagsbuchhandlung KG.

Esser, H. (2001). Integration und ethnische Schichtung [Integration and ethnic stratification] (Working Paper No. 40). Mannheim: MZES University of Mannheim. Retrieved from http://www.mzes.unimannheim.de/publications/wp/wp-40.pdf

Fararo, T. J., \& Skvoretz, J. (1987). Unification research programs: Integrating two structural theories. American Journal of Sociology, 92, 1183-1209.

Fawcett, J. T. (1989). Networks, linkages, and migration systems. International Migration Review, 3(3), 671-680.

Flatau, P., Smith, J., Carson, G., Miller, J., Burvill, A., \& Brand, R. (2015). The housing and homelessness journeys of refugees in Australia (AHURI Final Report No. 256). Melbourne: Australian Housing and Urban Research Institute Limited. Retrieved from http: //www.ahuri.edu.au/publications/projects/p82015

Fonds Soziales Wien. (2019). Flüchtlinge, Asyl und Grundversorgung. Grafiken und Daten zu Wien, Österreich und der EU [Refugees, asylum and basic care. Graphics and data about Vienna, Austria and the EU]. Vienna: Vienna Social Fund. Retrieved from https:// www.fluechtlinge.wien/export/sites/fluechtlinge/ downloads/FSW-FaktenFluechtlinge.pdf

Francis, J., \& Hiebert, D. (2014). Shaky foundations: Refugees in Vancouver's housing market. The Canadian Geographer, 58, 63-78.

Franklin, A. (2008). Ethnography and housing studies revisited. In P. J. Magin, S. Thomson, \& M. Tonts (Eds.), Qualitative housing analysis: An international perspective (pp. 271-289). London: Emerald Group Publishing.

Franz, Y., \& Gruber, E. (2018). Wohnen "für alle" in Zeiten der Wohnungsmarktkrise? Der soziale Wohnungsbau in Wien zwischen Anspruch und Wirklichkeit [Housing "for all" in times of housing market crisis? Social housing construction between ideal and reality]. Standort: Zeitschrift für Angewandte Geographie, 43(2), 98-104.

Giffinger, R., \& Reeger, U. (1997). Turks in Austria: Backgrounds, geographical distribution and housing conditions. In S. Ozuekren \& R. van Kempen (Eds.), Turks in European cities: Housing and urban segregation (pp. 41-66). Utrecht: University of Utrecht European Centre on Migration and Ethnic Relations.

Glaser, B. (1978). Theoretical sensitivity: Advances in the methodology of grounded theory. Mill Valley, CA: Sociology Press.
Granovetter, M. S. (1973). The strength of weak ties. American Journal of Sociology, 78(6), 1360-1380.

Granovetter, M. S. (1995). Getting a job: A study of contacts and careers. Chicago, IL: University of Chicago Press.

Gurak, D. T., \& Caces, F. (1992). Migration networks and the shaping of migration systems. In M. M. Kritz (Ed.), International migrations systems: A global approach (pp. 150-176). Oxford: Clarendon Press.

Hajek, P. (2019). Integrationsbarometer 2019. Integrationsbefragung. [Integration barometer 2019. Integration survey]. Vienna: Österreichischer Integrationsfonds.

Hatz, G., Kohlbacher, J., \& Reeger, U. (2015). Socioeconomic segregation in Vienna. A social oriented approach to urban planning and housing. In T. Tammaru, M. van Ham, S. Marcińczak, \& S. Musterd (Eds.), Socio-economic segregation in European capital cities. East meets West (pp. 80-109). New York, NY: Routledge.

Häuberer, J. (2019). The founding concepts of social capital: Bourdieu's theory of capital and Coleman's rational-choice approach to social capital. In J. Häuberer (Ed.), Social capital theory. Towards a methodological foundation (pp. 35-51). Basel: Springer.

Heckmann, F. (2015). Integration von Migranten. Einwanderung und neue Nationenbildung [The integration of migrants. Immigration and new nationbuilding]. Wiesbaden: Springer Fachmedien.

Hurlbert, J. S., Haines, V. A., \& Beggs, J. J. (2000). Core networks and tie activation: What kinds of routine networks allocate resources in nonroutine situations? American Sociological Review, 65, 598-618.

Kohlbacher, J., \& Reeger, U. (2007). Die Dynamik ethnischer Wohnviertel in Wien: Resultate einer Gebäudeerhebung 1981 und 2005 [The dynamics of ethnic housing areas in Vienna: Results of a buildingstock data collection 1981 and 2005]. Mitteilungen der Österreichischen Geographischen Gesellschaft, 149, 7-28.

Kohlbacher, J., \& Reeger, U. (2020). Globalization, immigration and ethnic diversity: The exceptional case of Vienna. In S. Musterd (Ed.), Handbook of urban segregation (pp. 101-117). London: Edward Elgar.

Kohlbacher, J., \& Schiocchet, L. (Eds.). (2017). From destination to integration: Afghan, Syrian and Iraqi refugees in Vienna (ISR Report No. 45). Vienna: ÖAW Publishing House.

Lauer, S. R., \& Yan, M. C. (2007). Neighbourhood houses and bridging social ties (Metropolis British Columbia Working Paper). Vancouver: Metropolis British Columbia.

Lichtenberger, E. (1984). Gastarbeiter. Leben in zwei Gesellschaften [Guest workers. A life in two societies]. Vienna: Böhlau.

Lin, N. (2001). Social capital: A theory of social structure and action. Cambridge: Cambridge University Press.

Massey, D. S. (1990). American apartheid: Segregation 
and the making of the underclass. American Journal of Sociology, 95, 1153-1188.

Massey, D. S., \& Denton, N. A. (1993). American apartheid: Segregation and the making of the underclass. Boston, MA: Harvard University Press.

McMichael, C., \& Manderson, L. (2004). Somali women and well-being: Social networks and social capital among immigrant women in Australia. Human Organization, 63(1), 88-99.

Müller, W. (2016, August 11). Mindestsicherung zieht Asylberechtigte verstärkt nach Wien [Means-tested minimum income increasingly attracts persons granted asylum to Vienna]. Der Standard. Retrieved from https://derstandard.at/2000042670101/ Mindestsicherung-zieht-Asylberechtigteverstaerkt---nach-Wien

Murdie, R. A. (2008). Pathways to housing: The experiences of sponsored refugees and refugee claimants in accessing permanent housing in Toronto. Journal of International Migration and Integration, 9(1), 81-101.

Murdie, R. A. (2010). Precarious beginnings: The housing situation of Canada's refugees. Canadian Issues/Thèmes Canadiens, 2010(Fall), 47-53.

Musterd, S. (Ed.). (2020). Handbook of urban segregation. London: Edward Elgar.

Peach, C. (1996). The meaning of segregation. Planning Practice and Research, 11(2), 137-150.

Pechtl, S. (2019, April 27). Yppenplatz: Wenn die Mieten immer teurer werden [Yppenplatz: When rents are increasing]. Un-ernst. Retrieved from https:// unernst.com/2019/04/27/yppenplatz-wenn-diemieten-immer-teurer-werden

Penninx, R., \& Garcés-Mascareñas, B. (2016). The concept of integration as an analytical tool and as a policy concept. In B. Garcés-Mascareñas \& R. Penninx (Eds.), Integration processes and policies in Europe. Contexts, levels and actors (pp. 11-29). Amsterdam: IMISCOE.

Putnam, R. D. (2000). Bowling alone: The collapse and revival of American community. New York, NY: Simon and Schuster.

Ronald, R. (2001). Ethnography and comparative housing research. International Journal of Housing Policy, 11(4), 415-437.

Ryan, L. (2011). Migrants' social networks and weak ties: Accessing resources and constructing relationships post-migration. The Sociological Review, 59(4), 707-724.

Smith, S. S. (2012). Why 'weak ties' help and 'strong Ties' don't: Reconsidering why tie strength matters. Berkeley, CA: Department of Sociology, University of California.

Stadt Wien Magistratsabteilung 17. (n.d.). Leitlinien der Wiener Integrations- und Diversitätspolitik [Guiding principles of Vienna's integration and diversity policy]. Stadt Wien. Retrieved from https:// www.wien.gv.at/menschen/integration/pdf/ integrationsleitlinien.pdf

Stadt Wien. (2019). Bevölkerungsstand: Statistiken [Population: statistics]. Stadt Wien. Retrieved from https://www.wien.gv.at/statistik/bevoelkerung/ bevoelkerungsstand

Statistics Austria, \& KMI. (2017). Migration und Integration: Zahlen, Daten, Indikatoren [Migration and integration: Numbers, data, indicators]. Vienna: Statistics Austria and Kommission für Migrations- und Integrationsforschung der Österreichischen Akademie der Wissenschaften.

Wiener Wohnen. (2019). Der Wiener Gemeindebau heute [Vienna's municipal housing today]. Wiener Wohnen. Retrieved from https://www. wienerwohnen.at/wiener-gemeindebau/wienergemeindebau-heute.html

Wohnungsboerse. (2020). Mietspiegel Wien [Rent index Vienna]. Wohnungsboerse. Retrieved from https://www.wohnungsboerse.net/mietspiegelWien/16688

Wren, K. (2007). Supporting asylum seekers and refugees in Glasgow: The role of multi-agency networks. Journal of Refugee Studies, 20(3), 391-413.

\section{About the Author}

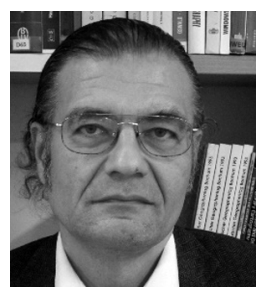

Josef Kohlbacher (PhD, DSocSci) is Deputy Director of the Institute for Urban and Regional Research of the Austrian Academy of Sciences in Vienna, Austria. For 30 years his research focus has been on immigration and integration in the urban housing and labour markets. Since 2015, projects related to Afghan refugees have become another important component of his research. 